\title{
The Limits to Judicial Independence: Cambodia's Political Culture and the Civil Law
}

\begin{abstract}
Distinctions between the common and civil law are crucial when considering the rule of law and judicial independence in a political system. The 1993 Constitution of the Kingdom of Cambodia provides for a democratic government with separation of powers, judicial independence and human rights guarantees consistent with international legal instruments. However, Cambodia ranks poorly in international indices of political interference and corruption in the judiciary and for the rule of law. Drawing on interviews with Cambodian state officials and legal practitioners, the article situates the domestic judiciary within the socio-political environment and constitutional arrangements in which it must operate and examines the limits to judicial independence in the country. The article argues that the lack of judicial independence in contemporary Cambodia is not only attributable to its neopatrimonial political culture but also to the legal-institutional framework established during the United Nations Transitional Authority in Cambodia (UNTAC) period. The legalphilosophical underpinnings of civil law, the nature of the civil law system operating in Cambodia, and how it is interpreted locally, are crucial to understanding the limits to judicial independence in the country.
\end{abstract}

Keywords: Cambodia, rule of law, political culture, civil law, judicial independence.

\section{Author Details:}

Dr Lucy West

Griffith Asia Institute

Griffith University

Nathan Campus, QLD 4111

Australia

lucy.west@griffith.edu.au 


\section{Introduction}

More than US\$10 billion has been spent by the international community on democratic statebuilding and good governance initiatives in Cambodia since the Paris Peace Agreements (PPA) were signed in 1991, and the deployment of the United Nations Transitional Authority in Cambodia (UNTAC), from 1992 to $1993 .{ }^{1}$ The 1993 Constitution of the Kingdom of Cambodia provides for a democratic government with separation of powers, judicial independence and human rights guarantees consistent with international legal instruments. Instead of the consolidation of democracy and respect for civil and political rights, however, Cambodia has subsequently become an authoritarian regime in the form of a de facto oneparty state under the rule of Hun Sen's Cambodian People's Party (CPP). ${ }^{2}$

Cambodia ranks poorly in international indices of corruption in the judicial system and for the rule of law-it is often the worst performer in the Asia Pacific region. For example, the 2016-2017 World Justice Project (WJP) ranked Cambodia 112 out of 113 countries surveyed globally on public perceptions of the rule of law. Of the fifteen countries surveyed regionally in East Asia and the Pacific, Cambodia came in last behind Myanmar. Of the eight primary rule of law indicators surveyed, Cambodia scored the lowest in "civil justice", the "absence of corruption" and "open governance". ${ }^{3}$ Cambodia also performed poorly on Transparency International's (TI) Corruption Perceptions Index with a rank of 161 out of 180 countries surveyed in $2017 .{ }^{4}$ Both indices highlight Cambodia's judiciary and courts as the most maligned of state institutions, plagued with corruption and political interference. Notably, these indexes are based on Western normative assumptions of a 'thick' or substantive rule of law. Despite advancing a comprehensive critique, rarely do these reports offer solutions toward a more effective judicial system that is sensitive to local conditions and institutions. 
In terms of successful rule of law promotion, Nicholson and Low argue that "political orientation and openness to liberal ideas" are "critical to legal transfers". 5 This article similarly holds that it is important to understand a country's rule of law in the context of what the prevailing political culture and institutional structure allows for. The article investigates the limits to judicial independence in contemporary Cambodia since 2010. Hun Sen's regime by 2010 , according to Heder, had become "more militarized ... less democratic, and more characterised by 'lawfare"". 6 The regime has continued its shift away from the targeted violence against political opponents that was seen in the 1990s and early-2000s, coming to rely more on the new Criminal Code introduced in 2010, which effectively outlawed criticism of Cambodia's judiciary. ${ }^{7}$

In accounting for the lack of judicial independence in Cambodia, political scientists have tended to focus on political culture explanations in the form of patron-clientelism derived from traditional Khmer culture, which in combination with the country's turbulent history of Khmer Rouge genocide, communist Vietnamese rule, and external intervention, has developed into modern neopatrimonialism. Neopatrimonialism describes the process of the traditional patrimonial authority becoming retained by the modern post-colonial state form. This adaptation denotes "hybrid political systems in which the customs and patterns of traditional patron-clientelism co-exist with, and suffuse, rational legal institutions". ${ }^{8}$ The outcome is that while public rules are "formal and rational", their "social practice is personal and informal". ${ }^{9}$ In this view, the institutions of the Cambodian state are manipulated by a predatory $\mathrm{CPP}$ elite to extract resources from society to service the comprehensive and pervasive systems of patronage required to maintain political power. ${ }^{10}$ 
In explaining the limits to judicial independence in Cambodia, this article suggests that greater attention needs to be focused on the institutional design established by the 1993 Constitution. The article argues that the lack of judicial independence in contemporary Cambodia is attributable to the combination of the country's political culture and the legalinstitutional framework established during the UNTAC period. A civil law system in a neopatrimonial context is a legal-institutional structure highly susceptible to political interference. The legal-philosophical underpinnings of civil law, the nature of the civil law system operating in Cambodia, and how it is interpreted locally, are crucial to understanding the limits to judicial independence in the country.

Evidence for this study was gathered through interviews conducted in September 2015 and July 2016 with spokespersons for the Council of Ministers and Ministry of Justice, National Assembly members, judges and other judicial officers, lawyers, local non-government organisation (NGO) workers, international non-government organisation (INGO) workers, independent researchers, and foreigners operating within the Cambodian legal sector. This evidence provides insight into how Cambodian government officials, legal practitioners and civil society actors understand the purpose and operation of the country's civil law system. The evidence from the interviews shows how Cambodia's neopatrimonial political culture interacts with the constitutional structure established by UNTAC to undermine judicial independence in the country.

Significant empirical research has been done since the withdrawal of the UNTAC mission in 1993 on the obstacles to the rule of law and respect for human rights in Cambodia. This work has focused on deficiencies in the separation of powers, judicial independence, horizontal accountability between institutions, vertical accountability between government and civil 
society, lack of bureaucratic capacity and resourcing in the legal sector, as well as a lack of cooperation between police and the judiciary. ${ }^{11}$ Whether explicit or implicit, the underpinnings of much of this literature assumes that Western notions of civil and political rights, and a rule of law that safeguards them, are the normative standard for comparison. More specifically, these normative underpinnings tend to reflect the fundamental legalphilosophical assumption of Anglo-American common law - that the purpose of the rule of law is to ensure and maximise individual liberty. To this end, most common law systems typically feature a robust separation of powers, with an authoritative judicial check on executive power, and the capacity for courts and judges to not only strike down laws, but also to make law through precedent.

There is a fundamental tension between these common law assumptions and the legalphilosophical basis of Continental European-derived civil law systems, such as in Cambodia. Civil law systems are designed to give expression to the will of the legislature, whereby statutes are the primary source of law. Given this, judicial review mechanisms, particular with respect to public law_ and therefore the separation of powers - are typically weaker. The implications of this distinction are that in civil law jurisdictions an underlying liberal political culture given expression through legislation and behavioural norms is crucial to securing the judicial independence sought by Western donors and the international community. These necessary attributes are almost completely absent in the Cambodian setting with its neopatrimonial political culture, CPP hegemony and "no concept of a loyal opposition as another check on power". ${ }^{12}$ The CPP embraces the trappings of electoral democracy because it facilitates the patron-client exchange process, while at the same time working to limit true democratic practice because it threatens to eradicate the political system its authority rests upon: neopatrimonialism. 
It must be recognised that UNTAC inherited a massively dysfunctional legal system, which was a damaged hybrid of traditional customary laws, a residue of French colonial civil law, and the more recent Vietnamese legislation and court system from the People's Republic of Kampuchea (PRK) (1979-1989), which was primarily influenced by the socialist model. ${ }^{13}$ The effects of Cambodia's political culture on judicial independence are exacerbated, however, by the constitutional structure established in the UNTAC period, which was primarily designed with the immediate goal of making peace between warring factions to allow for great power disengagement from decades of conflict in Indochina. ${ }^{14}$ With the benefit of hindsight, a parliamentary system where the executive sits within and controls the legislature, in combination with a civil law system, constitutes a 'perfect storm' for judicial independence in a country with a political culture such as Cambodia. Rather than providing the basis for good governance along the liberal lines of the text of the 1993 Constitution, the institutional design established during the UNTAC period has instead contributed to the deficient functioning of the judiciary.

In developing this argument, the article proceeds through three sections. The first examines the legal-philosophical and institutional differences between common and civil law systems with respect to the rule of law, and shows how Cambodian state elites understand these distinctions very well. The second addresses the concept of judicial independence, before examining the reasons for pervasive executive interference in the Cambodian judiciary, which takes the form of direct political intervention and a culture of self-censorship on the part of judges and other legal actors. The third analyses the relationship between judicial independence and the separation of powers with a focus on the lack of effective judicial review provisions in Cambodia's constitutional arrangements. 


\section{Civil and Common Law Systems and the Rule of Law}

There is a strong normative claim that the rule of law is a fundamental component for any well-functioning democracy. This assumption is problematic in that the definitions of the rule of law that are dominant in political science and democratisation scholarship are based on pre-existing liberal values that are not present in many societies. Indeed, the countries that appear at the top of the governance, freedom, development, and rule of law indices are all either Anglo-American common law systems, civil law jurisdictions located in northern Europe, or are substantially "westernised". ${ }^{15}$ It is also important to consider the distinction between the common and civil law traditions for the rule of law and judicial independence in non-liberal contexts.

The common law tradition originated in England and was transplanted to North America and other British colonies. It developed mainly to "protect the property of individuals and to limit the power of the state". ${ }^{16}$ The civil law tradition originated in Continental Europe and has since spread around the world through colonialism, emulation and its greater ease of implementation. There are a number of families of civil law, the most prominent being French civil law, which was developed from the post-revolutionary Napoleonic Code. Civil law developed "in the context of an expanding empire in need of regulation" and therefore it is "articulated in terms of the rights and duties of the citizen". ${ }^{17}$ Civil law holds the idea that the state is supreme and the role of the individual is to submit to it; it developed to regulate its citizenry rather than to protect the private sphere from an encroaching state. ${ }^{18}$ The two systems are fundamentally different from a legal-philosophical perspective, with clear implications for the concepts of the rule of law and judicial independence. 
The foundational difference between the common and civil law traditions lies in the main source of law. The British common law tradition makes extensive use of statutes, but judicial cases are regarded as the most important source of law. Courts are mandated to develop and interpret a body of case law to supplement statutory law. ${ }^{19}$ In a common law system, judges enjoy a great degree of autonomy because they can actively develop rules. The common law system "developed from case law and that the doctrine of precedent was then necessary to give a stability to the system as a whole, whereas the role of case law in civil law countries was restricted to filling in the gaps that may have been left by the legislator". ${ }^{20}$ In civil law systems, comprehensive statutes are the primary source of law, with custom and case law playing only a very minor role. ${ }^{21}$ Courts and judges thus do not generally have an important role in the making of law; rather their role is to independently adjudicate, apply, and enforce the law, as it is legislated.

In a strictly legal sense, civil law systems can only provide for a 'thin', procedural rule of law. A procedural rule of law is defined as laws that are publicly promulgated in an established manner; clear, stable and generally applicable to guide prospective action by all citizens; and applied and enforced equitably by a judiciary independent from political or other external interference that is accessible to all. ${ }^{22}$ As this definition indicates, the substantive 'content' of the law is conceived as separate to the 'rule' of law. ${ }^{23}$ To promote and protect substantive outcomes such as civil and political rights and socio-economic development, the onus on the legislature to make 'good' laws is thus much higher in a civil law system than in a common law system. This in turn relates to the constitutional structure of the executive and legislative branches and the political culture on which they rest. To produce substantive rule of law outcomes in a civil law system - in terms of human rights and good governance consistent with international standards - requires a broadly accepted 
liberal democratic civic culture that is given expression through legal codes and their implementation.

Civil law is the dominant legal tradition in Europe, Latin America and in most parts of Asia and Africa. ${ }^{24}$ Nedzel states that 90 per cent of countries in the world follow a civilian or "code based" legal system. ${ }^{25}$ Apart from the former British colonies of Singapore and Malaysia, and the mixed systems in Myanmar and the Philippines, all non-socialist legal systems in East Asia are based on civil law traditions that began to be developed in the nineteenth century. ${ }^{26}$ More recently, scholarship has focused on a state's legal tradition as being a potential factor for rule of law variation. Scholars have argued that common law systems perform better than their civil law counterparts in adhering to the rule of law. ${ }^{27}$ For example, Glaesner and Shleifer conclude that at similar levels of development, "civil law countries exhibit heavier regulation, less secure property rights, more corrupt and less efficient governments, and ... less political freedom than do the common law countries". ${ }^{28}$

The rule of law as a concept means notably different things across the civil and common law traditions. Not only are there distinctions in terms of definition, but at a deeper level there are also differences in how the law itself is conceived. The common law definition of the rule of law regards the law to be "pre-eminent and government [to be an] association that follows strict, transparent procedures to prevent favouritism and instrumentalism". ${ }^{29}$ The law is therefore considered to be above the government, because the government is subject to it. In contrast, the rule of law in a civil law tradition, état de droit, effectively means 'rule through law', and where the common law tradition puts law as sovereign above any government, the civil law tradition holds that the lawmaker is sovereign. ${ }^{30}$ With a civil law system, there is 
greater institutional capacity for the government to manipulate the judiciary in illiberal cultural settings such as Cambodia.

Importantly, the 'globalised' substantive definition of the rule of law familiar in political science scholarship fails to engage with significant components of the civil law concept. In a common law system, the rule of law means that

governmental powers are circumscribed and limited by both the law itself and by structural and procedural components that work to deter politicization and corruption. Furthermore, it is these structural and procedural components that help protect individual liberty and promote economic development. ${ }^{31}$

The civil law tradition, or Continental European 'rule through law' notion, implies simply that "those subjected to a state's laws [shall] not be treated arbitrarily". ${ }^{32}$ Unlike the rule of law in a common law tradition, this definition does not prioritise civil liberties as an outcome of the law. A civil law tradition views the rule of law as instrumentalist, in the sense that it seeks to direct society towards a goal, however conceived by legislators. This position is in contrast to the common law conceptualisation of the rule of law, which is non-instrumentalist and aimed at minimising interference with individual liberty. ${ }^{33}$

In Cambodia, an instrumental view of the law, consistent with a civil legal system, is clearly demonstrated by the attitudes of elites. For example, Prime Minister Hun Sen wrote in 2009, with respect to the rule of law:

After 1979, the country undertook to rebuild its governance regime and to build a rule of law that is effective and anchored in our reality, and that is adapted to our needs and our capacity to implement. There is no miracle recipe. We only know essential ingredients. ${ }^{34}$

In commenting on the relationship between the executive and the judiciary, a spokesperson for the Ministry of Justice elaborated that:

Cambodia is a civil law system and we have recently implemented three new laws; this is the first time that we have a formal legal structure and standards to govern the 
legal system in Cambodia. We adopted these [laws] from France and Germany, where the independence of the court is only the adjudicating function, but the administration, financial management and personnel are under the Ministry of Justice. This has been criticised by people who support a common law system, who want to see the court separate from the executive, not just the adjudicative but also the administration function. But the Constitution states that the court is independent, but we need to make a law stating what is meant by 'independence' and to what extent the court is independent. Now we have the law on court organisation and this defines clearly that the independence of the judiciary is only for adjudicating function, for administration function [that] is under the Ministry of Justice. ${ }^{35}$

This quote illustrates that Cambodian state elites are well-versed in the civil law and its theoretical and practical differences with common law systems. Judges and courts are constitutionally mandated to investigate cases and adjudicate based on existing laws only. This highlights how the substantive content of the law and the social outcomes to which it is directed are conceived as separate to the rule of law, and not within the purview of the judicial branch. Substantive rule of law outcomes in a civil law jurisdiction requires that the content of the law and behavioural norms of governance reflect liberal democratic assumptions, as they do in European Union (EU) states and in Japan, for example. Where they do not, civil law systems are less likely to deliver an effective rule of law with a wellfunctioning, independent judiciary.

\section{Rule of Law and Judicial Independence}

This article suggests that in a neopatrimonial political context such as Cambodia, a parliamentary system with only nominal separation between the executive and legislature, along with a civil law judicial branch, is a constitutional framework that is highly susceptible to political intervention and executive dominance of the judicial system. Judicial independence is often categorised by two features; firstly “judicial autonomy or freedom from interference from other individuals and institutions"; and secondly, as "the requirement for judges to render impartial decisions". ${ }^{36}$ Both categories of judicial independence are consistent with thin and thick definitions of the rule of law, and with civil and common law 
systems. An independent judiciary is primarily valued for its ability to place limits on the exercise of arbitrary power by current office holders. ${ }^{37}$ Larkins states that judicial independence becomes most significant when the executive is involved in a dispute, as this is when rule of law concerns are typically exposed. ${ }^{38}$ This highlights the most important aspect of judicial independence - that judges and the judicial branch are not subject to influence and control by the political regime or powerful individuals within it, or associated with it. More broadly this refers to the insularity of the judiciary as an institution; to not be subjected to coercion or interference in its processes, or to be used as a tool for political purposes or economic gains. Larkins asserts that "the rule of law is not secure when the body for its enforcement is composed of judges who either fear challenging the government or are already predisposed toward declaring its deed legal". 39

In contemporary Cambodia we see both direct executive interference in the judiciary and a culture of self-censorship whereby judges and legal practitioners render decisions they know to be in the interests of the regime without necessarily receiving instructions. One senior Cambodian Government official commented that “the nation isn't ruled by a person ... but sometimes he [Prime Minister Hun Sen] has to react to manage it". ${ }^{40}$ This statement strongly validates the practice of the executive becoming directly involved in judicial matters when it deems it to be necessary. Executive interference in the judiciary manifests at the highest levels. For example, Hun Sen, has personally and publicly claimed responsibility for interceding in judicial cases. In April 2015, a woman crashed into the Prime Minister's mansion, seriously injuring two bodyguards. Days later Hun Sen publicly announced in an inauguration speech that he personally intervened in order to secure the woman bail: “[1]uckily, I personally called the [Phnom Penh Municipal] Court's president and made a request". ${ }^{41}$ 
In March 2016, the Prime Minister took to social media to urge the granting of bail for two community representatives involved in a long-standing land dispute. Hun Sen referred to the Kampong Speu court's decision to detain the two as "very disappointing" and also admitted to having a personal role in interceding: "I ordered the governor to work with the court tonight to release them on bail". ${ }^{42}$ The Prime Minister also publicly criticised the Supreme Court as "unjust" when it dismissed an appeals case relating to a land ownership dispute between a family and five soldiers. The Prime Minister stated he had to tell both provincial and military authorities to block the soldier's eviction: "I had to work to delay the implementation", he was quoted as saying. ${ }^{43}$

Interview respondents suggested that instances of executive interference in the judiciary are not always regarded as a problem in Cambodia by the general population; rather, executive interference is seen as necessary and even appropriate at times. Cambodian government officials contend that "the head of the executive branch may need to say something in order for the law to be enforced better to maintain public order and social security". ${ }^{44}$ In response to the Prime Minister publicly expressing his views on a legal case and calling for arrests, a spokesperson for the Ministry of Justice said that:

Sometimes the Prime Minister expresses his opinion on highly publicised cases, and sometimes he takes actions like ordering the arrest of some suspects. Critics argue this is not ensuring the independence of the judiciary. But from the government's perspective this is not interference, this is merely the executive expressing their opinion [regarding] the enforcement of the law. It is the authority of the executive branch because the executive controls the police and armed forces and they are obligated to prevent any criminal act or wrongdoing in society, they need to ensure societal and public order. ${ }^{45}$

A Council of Ministers' spokesperson said, "sometimes the government has to react because the government is elected by the people not the judges". ${ }^{46}$ At times the executive has to become involved in judicial affairs when the courts are regarded as corrupt or incompetent. However, this executive interference reinforces to the public that the courts are dysfunctional. 
The spokesperson further added that sometimes the courts dropped cases and released guilty individuals, forcing the Prime Minister to become involved: "people blame the Prime Minister for interfering in the court [but] he has to [because] there is no justice happening in the courts and it is policy". ${ }^{47}$

In addition to overt political interference, the prevailing neopatrimonial political culture encourages self-censoring and inertia by judges and legal officials. This is because legal officials are reluctant to take action if the views of political elites are not clear. The Extraordinary Chambers in the Courts of Cambodia (ECCC), for example, has received intense criticism from the international community regarding allegations that the Cambodian government is directly determining the outcome of cases through interference and intimidation of the national judges ${ }^{48}$ However, an international staff member at the ECCC stated that in his observations:

I don't believe the government is telling them [the judges] what to do in each case, I believe they are self-censoring in terms of what they believe may be accepted and not accepted. It is just as much a matter of integrity amongst the national judges and they will vote based on what they believe is desired from the people in power, not necessarily because they have been instructed to do so. ${ }^{49}$

Judges are appointed by the government and they know the parameters within which they have to operate. Direct orders from the executive are often not necessary. With respect to the ECCC, the respondent said: "I think there is a degree of confidence from the ruling party that those national judges at the ECCC will deliver verdicts which are aligned with the wishes of the party". The respondent further commented: "Their perception of room for manoeuvring is guiding their decision ... they know there is some room but there are also some boundaries that they cannot overstep". This culture of self-censorship governs all of Khmer society, he commented. ${ }^{50}$ These acts of self-censorship can be linked to Khmer cultural norms of elitism and hierarchy. Although the court is structured as a hybrid model, the Cambodian component 
is vulnerable to political manipulation due to a lack of impartiality and independence from Hun Sen's CPP regime. In 2010, for example, Hun Sen publicly expressed his opposition to the tribunal expanding its jurisdiction beyond the original four indictments in cases 001 and 002 in the interests of state stability. ${ }^{51}$

When commenting on whether it was cultural or institutional reasons for judicial interference and self-censorship in Cambodia, a practising lawyer responded that both played a role. In terms of the institutional arrangements, he commented that there is no separation between political institutions and in the judiciary and judges were often members of the ruling party. ${ }^{52}$ In terms of cultural reasons for why the law is not applied equally at all times, he referred to Khmer culture respecting those who are in a more senior position: "[Prime Minister] Hun Sen is the strong man in Cambodia, and most government officials only respect him, they don't respect the law ... it is the culture. If Prime Minister Hun Sen says [what is] right or wrong, most people go along with it". 53

Within comparative politics there is the tendency to frame judicial independence with the assumption of a strict separation of powers between the executive, legislative and judicial branches of government. ${ }^{54}$ Deinla suggests that this notion is deeply rooted in the philosophical foundation of Anglo-American liberal democracies, where the separation of powers and adequate checks and balances on the government are deemed essential requirements for a robust rule of law to protect individual liberty. ${ }^{55}$ In civil law-derived systems, however, the separation of powers between lawmakers and the judicial system is conceived quite differently. ${ }^{56}$ 


\section{Judicial Independence and the Separation of Powers}

Judicial independence is often evoked when discussing the separation of powers between the legislative, executive and judicial branches. Through judicial review mechanisms, an independent judiciary is constitutionally mandated to ensure adequate checks and balances are in place to prevent a concentration of power. However, the common and civil law traditions not only have legal-philosophical, but also structural differences regarding the role of the judiciary, which influences judicial review and the notion of the separation of powers. Mahoney states,

The fundamental structural distinction between the common law and civil law lies in the judiciary's greater power to act as a check on executive and legislative action in a common-law system. Thus, although both the common and civil law provide strong protections for property and contract rights against other private actors, those rights may be more secure against the government itself in a common-law system. ${ }^{57}$

This is a very important distinction to understand for judicial independence in the Cambodian context: that the structure of the civil law cannot provide citizens with the same protections against the government as in a common law system, which feature much stronger judicial review powers in concrete cases.

The structure of court systems and judicial review mechanisms are also quite different in civil law systems compared with common law jurisdictions. Rather than a unified hierarchical system of courts, as in the common law, with a Supreme or High court at the apex, civil legal systems are typically divided into the private and public law, with separate court systems for each. Private law relates primarily to civil and commercial codes - in regulating relations between private citizens and private bodies within society. Public law regulates the relations of state agencies with one another, and the relations of the state to its citizens and private bodies. Public law generally consists of constitutional, administrative and criminal law. ${ }^{58}$ 
Considering judicial independence and the separation of powers, we are primarily concerned here with the judicial review of public law.

Given that civil law judges in the regular courts must apply the law as legislated in an abstract sense, rather than re-interpret it for particular cases, appellate functions and judicial review mechanisms in civil law systems take the form of separate, extraordinary courts for the different branches of private and public law. This is different to common law systems, where a Supreme or High Court is the highest court in a unified system, acting as the ultimate court of appeal for civil and criminal matters, but also dealing with matters of constitutional and administrative law. In common law systems, Supreme Courts typically have strong constitutional and normative power to strike down legislation and executive regulation deemed unconstitutional, and in some jurisdictions there is a tendency towards judicial activism. This power can only be exercised in the context of litigation, however, which is considered a 'concrete' method of review. ${ }^{59}$

This, again lies in contrast to a civil law system, where special constitutional and administrative courts outside the structure of regular courts, review legislation and regulations in the 'abstract' only. Their responsibility and powers of review differ by jurisdiction in terms of whether legislation is reviewed before or after it is enacted; whether or not courts have constitutional authority to strike down or amend laws; whether this power is shared with other branches of government; or whether the court's role is advisory only. ${ }^{60}$ Thus, the capacity of the judiciary to act as an independent check on executive and legislative power is normatively weaker and dependent institutionally on the national context in terms of the composition and constitutional role of review courts. Since constitutional review is "value-laden" and "may represent a highly political decision", appointments to these courts 
are often of a "political nature". ${ }^{61}$ Similarly, judges in administrative review courts are public servants themselves, and susceptible to "internalize pro-government perspectives and in this sense become non-independent". ${ }^{62}$ It is for these reasons that civil law systems with their weaker judicial review provisions have increasingly been criticised for being too "amenable to the political machinations of corrupt and oppressive political regimes". ${ }^{63}$

While in theory the text of the 1993 Cambodian Constitution provides for a constitutional monarchy with robust separation of powers and the protection of judicial independence, an assessment of the judiciary in the local political context reveals major inconsistencies and tensions between these constitutional arrangements and Cambodia's political reality. Article 51 of the Constitution states that "the Kingdom of Cambodia adopts a liberal multi-party democratic policy" and that "the legislative, executive and judicial powers shall be separate". ${ }^{64}$ The Constitution adopts a parliamentary system of democracy where the executive sits within the legislature as in the United Kingdom, Australia, Japan or Germany, rather than a presidential system of government, with its strict separation between executive and legislature, as in the United States or France. ${ }^{65}$ On paper the Cambodian Constitution sets out the conditions for a liberal democratic state, but this exists in theory only. There is significant overlap in the functions of the executive and legislature, which Hauerstein describes as "institutionally, functionally, and personally strongly interconnected". ${ }^{66}$ The Ministry of Justice administers the judicial system, so the judiciary cannot be said to be independent of the executive ${ }^{67}$ This is not unusual in liberal constitutional arrangements, whether common or civil law jurisdictions, but in the Cambodian context of neopatrimonialism, this administrative structure exacerbates the system of patronage. This is because personal and informal political and social relationships, characterised by deference to those higher in the chain of patronage, infuses formal administrative structures. 
For example, the Supreme Council of Magistracy (SCM) is the body responsible for the appointment of judges and prosecutors, as well as taking any disciplinary action against judges or prosecutors. The SCM is responsible for recommending to the King proposals regarding the appointment, transfer, secondment, leave of absence, delineation of duties, promotion and dismissal of judges and prosecutors. Article 134 of the Constitution states that the SCM shall be appointed by the King. ${ }^{68}$ The Law on the Organisation and Functioning of the Supreme Council of Magistracy was first adopted in 1994 by the National Assembly. The Law states that the SCM should be the primary body for upholding judicial independence and ensuring the integrity of judges. However, the 1994 law also allowed for the King to delegate authority for overseeing the SCM to the Minister of Justice, thereby entrenching executive control of the judiciary. ${ }^{69}$ With judicial appointments, salaries and employment protections controlled by the regime through the SCM, Cambodia's patronage system results in judges operating courts and making rulings deferential to the regime's interests. ${ }^{70}$

According to Un, this structure of the SCM and its politicised nature has allowed the CPP to control the courts. ${ }^{71}$ Senior CPP members sit on the SCM, which means that it "has consistently failed to protect judges from interference with judicial independence by the justice minister or other ministry officials, the Council of Ministers, and other members of the government, armed forces, gendarmerie, or police". ${ }^{72}$ In July 2014, three long-awaited judicial reform laws were signed into effect by the Cambodian King, including a new Law on the Organisation and the Functioning of the Supreme Council of Magistracy. According to Human Rights Watch, rather than improving the rule of law and integrity of the judicial system, the new law on the SCM effectively amounts to a complete CPP takeover of the courts. This is because the laws put the Minister of Justice at the centre "of all key decision- 
making by the judiciary and by the Supreme Council of the Magistracy (SCM), the body charged with appointing, disciplining, and overseeing the country's judicial system". ${ }^{73}$

Judges within the courts typically comply with political pressure because of fear and coercion. The civil society actors interviewed stated that prosecutors and judges do not necessarily want to execute decisions given to them by senior officials. However, they have no choice because they are concerned about "losing their job", "facing trouble", and for their own safety and that of their family. ${ }^{74}$ The example of Banteay Meanchey's Provincial Court Chief Prosecutor, Phann Vanrath, who was removed from his position was given: "whenever the government wants to remove a judge it is easy ... all these issues have made judges and prosecutors scared and afraid, and they would not dare go against the government or whatever the government wants them to do". ${ }^{75}$

In theory the formal elements of the separation of powers and judicial independence are enshrined in Cambodia, but in reality this is a very different case. Along with executive domination of court administration and the National Assembly, the lack of a genuine separation of powers is exacerbated in Cambodia with its civil law system where, in the absence of case law, judges have a weaker capacity to test the constitutionality of legislation and executive decrees compared with Anglo-American common law systems.

Established only in 1998, the Constitutional Council is the primary organ of judicial review in Cambodia. The Constitution provides the Constitutional Council with relatively robust powers of judicial review. This includes "ex ante and ex post control of laws ... and even allows courts to refer cases to the Constitutional Council if the Constitutionality of a law is in doubt. ${ }^{76}$ In truth, however, the Constitutional Council has lacked the independence required 
for the judicial review provided for in the Constitution. Appointments to the Council are politically-motivated by the CPP, including candidates lacking verifiable law degrees or legal experience. The Constitutional Council is deeply politicised, with up to six of the nine members belonging to the CPP. ${ }^{77}$

The absence of specific mention of Cambodian judicial review provisions in interviews undertaken for this research suggest they are not widely known or understood, even by many legal practitioners. Many civil society respondents alluded to judicial review in mentioning the lack of a meaningful 'separation of powers' and judicial independence in Cambodia. However, their responses often reflected common law understandings, perhaps influenced by Anglo-American donors, betraying a lack of understanding of Cambodia's constitutional provisions in this respect.

One respondent working at a local research institution, for example, stated that the rule of law should "emerge from a system of checks and balances ... we cannot just depend on politicians to implement those laws ... there needs to be a mechanism to propel them to enforce those laws, not just based on their willingness to do it, that is really not enough". ${ }^{78}$ He further elaborated:

The judiciary is considered to be very corrupt and highly impartial and basically under the control of the ruling party. If you look at the important state institutions that in a liberal democratic country have a role to check and balance the government, here in Cambodia they cannot function like that ... the executive is too powerful to be constrained by laws. This explains why the rule of law in Cambodia cannot function well. ${ }^{79}$

A Cambodian lawyer stated similarly, "the Government has the power to control almost everything in Cambodia". He further commented that there is no separation between political institutions and in the judiciary, and that judges were often members of the ruling party. ${ }^{80}$ In terms of institutional arrangements, the lawyer invokes a common law understanding in 
referring to a strict separation of powers between the executive and judiciary. This is an example of how Cambodia's legal tradition is overlooked or misunderstood when making assessments about judicial independence the state's rule of law quality.

\section{Conclusion}

The limits to judicial independence highlighted in this article are partly attributable to the flaws in Cambodia's constitutional arrangements and institutional design established during the UNTAC period. A parliamentary system with a civil law judicial branch is the least likely constitutional arrangement to provide for a functioning and independent judiciary in the neopatrimonial Cambodian political setting. Parliamentary systems, where the executive sits within the legislature, allow for the centralisation of political power, while the social purpose of a civil law system is to give expression to the will of the legislature. In Cambodia, this means that the judiciary is an instrument of the executive, thus undermining any functioning separation of powers. This is exacerbated by the weaker provisions for judicial review in civil law systems, where the constitutionality of laws can only be tested in the abstract and not in concrete cases involving the government. In the absence of a liberal political culture with behavioural norms that respect the separation of powers, the legal system in Cambodia will not deliver even a thin rule of law. This is often overlooked by the international community when making assessments about Cambodia's rule of law quality and seeking to promote judicial reforms.

Statements by Cambodian government officials regarding their interpretation of the rule of law suggest that local political elites do not view the rule of law as an international normative standard to strive towards. Instead, the rule of law is understood instrumentally as a resource by which the government regulates society, and one that should be tailored to the local 
Cambodian context. The evidence examined in the article demonstrates that executive interference in the judiciary is deep and extensive. This is through direct interference in some cases, but also through an entrenched and pervasive culture of self-censoring by judges and other legal actors. Legal actors will often not act until they receive instructions from higher authorities, which are regarded as more important than the law. The evidence also suggests that judges regularly rule in favour of regime interests without being directed to do so. Given that the judiciary is perceived as highly corrupt, executive interference, particularly from the Prime Minister, is seen as positive and in the interests of justice in some cases, which serves to further undermining confidence in the judicial system.

The rule of law requires a normative commitment by elites to the proposition that the state and its institutions not only operate according to law, but that individuals representing the state are subject to the law like any other citizen. This imperative is heightened in a civil law system, in which the capacity of the judiciary to act as a check on power is structurally weaker. In Cambodia's civil law system, the judicial branch is not constitutionally empowered to challenge the decisions of the legislative and executive branches in concrete instances that are tested in the courts. This supports the argument that with the parliamentary system and civil judicial branch established during the UNTAC period, Cambodia does not have the institutional provisions to provide an effective system of checks and balances. Although Cambodia has a similar constitutional framework and legal-institutional structure to a number of liberal democratic countries such as Germany, Denmark and Japan, it displays profoundly different outcomes in terms of judicial independence and the rule of law. This article concludes that the international community, when considering governance and state building initiatives, needs to be more sensitive to the interplay between institutional design, political culture, and local understandings of the purpose and nature of the rule of law. 
${ }^{1}$ Peou, "“Peace through Retribution or Reconciliation?" 341.

${ }^{2}$ Gainsborough, "Elites vs. Reform," in Laos, Cambodia, and Vietnam', 37-38; McCarthy and Un, "The Evolution of Rule of Law in Cambodia".

${ }^{3}$ World Justice Protect, WJP Rule of Law Index 2016.

${ }^{4}$ Transparency International, Corruption Perceptions Index 2016.

${ }^{5}$ Nicholson and Low, "Local Accounts of Rule of Law Aid," 4.

${ }^{6}$ Heder, "Cambodia in 2010", 208..

${ }^{7}$ Article 523, Discrediting the Court Decision, of the revised 2010 Penal Code outlines that a person who criticises a "judicial act or decision" aiming to "endanger Cambodian institutions" can be sentenced up to six months in prison and a one million riel fine.

${ }^{8}$ Bratton and Van de Walle, Democratic Experiments in Africa, 62.

${ }^{9}$ Erdmann and Engel, "Neopatrimonialism Reconsidered," 114.

${ }^{10}$ McCarthy and Un, "The Rule of Law in Illiberal Contexts".

${ }^{11}$ See, for example, Un, "The Judicial System and Democratization in Post-Conflict

Cambodia."; Piergigli, "Transition to Democracy and the Protection of Fundamental Rights."

12 Roberts, Political Transition in Cambodia 1991-99, 35.

${ }^{13}$ Bull, No Entry without Strategy, 75.

${ }^{14}$ Roberts, Political Transition in Cambodia 1991-99, 37.

${ }^{15}$ Nedzel, "The Rule of Law," 60.

${ }^{16}$ Møller and Skaaning, The Rule of Law, 154.

17 Joireman, "Colonization and the Rule of Law," 316.

18 Ibid

${ }^{19}$ Helmke and Rosenbluth, "Regimes and the Rule of Law," 347.

${ }^{20} \mathrm{Yu}$, "The Role of the Judge in the Common Law and Civil Law Systems," 35-36.

${ }^{21}$ Merryman, Clark and Haley, The Civil Law Tradition, second edition, 938.

${ }^{22}$ Raz, The Authority of Law, 213-219; Peerenboom, Varieties of Rule of Law, 2-3.

${ }^{23}$ Cheesman, "Thin Rule of Law or Un-Rule of Law in Myanmar," 599.

${ }^{24}$ Merryman and Pérez-Perdomo, The Civil Law Tradition, second edition, 4.

${ }^{25}$ Nedzel, "The Rule of Law," 80.

${ }^{26}$ Merryman, Clark and Haley, The Civil Law Tradition, second edition, 6-7.

${ }^{27}$ Joireman, "Colonization and the Rule of Law."; Eisenberg, The Nature of the Common

Law.

${ }^{28}$ Glaesner and Shleifer, "Legal Origins," 1194.

${ }^{29}$ Nedzel, 'The Rule of Law', 108.

${ }^{30}$ Ibid., 61.

${ }^{31}$ Ibid.

${ }^{32}$ Ibid., 65

${ }^{33}$ Oakeshott, On Human Conduct, 119.

${ }^{34}$ Sen, "The Rule of Law in Cambodia," 10.

35 Ibid.

${ }^{36}$ Deinla, "Public Support and Judicial Empowerment of the Philippine Supreme Court," 130.

${ }^{37}$ Burbank, "What do we Mean by 'Judicial Independence'?"

${ }^{38}$ Larkins, "Judicial Independence and Democratization," 608.

${ }^{39}$ Ibid.

${ }^{40}$ Interview with a spokesperson for the Council of Ministers, Phnom Penh, September 2015.

${ }^{41}$ Quoted in Sony, "PM Asked Drunk Driver Be Released On Bail."

${ }^{42}$ Quoted in Dara and Kong, "PM Intercedes in Kampong Speu Jailings." 
${ }^{43}$ Quoted in Dara and Turton, "PM Overrules Supreme Court's Decision in Banteay Manchey Land Dispute."

${ }^{44}$ Interview with a spokesperson for the Ministry of Justice, Phnom Penh, September 2015.

${ }^{45}$ Ibid.

${ }^{46}$ Interview with a spokesperson for the Council of Ministers, Phnom Penh, September 2015.

${ }^{47}$ Ibid.

${ }^{48}$ Bertelman, "International Standards and National Ownership?" 343; Un and Ledgerwood, "Is the Trial of 'Duch' a Catalyst for Change in Cambodia's Courts?"; Un, "Cambodia in 2011."; Un, "The Khmer Rouge Tribunal."

${ }^{49}$ Interview with international staff member at the ECCC, Phnom Penh, September 2015.

${ }^{50}$ Ibid.

${ }^{51}$ Peou, "Peace through Retribution or Reconciliation?" 342.

52 Interview with Cambodian lawyer, Phnom Penh, September 2015.

${ }^{53}$ Ibid.

${ }^{54}$ Bedner, "An Elementary Approach to the Rule of Law," 68.

${ }^{55}$ Deinla, "Public Support and Judicial Empowerment of the Philippine Supreme Court," 130.

${ }^{56}$ Glendon, Wallace and Osakwe, Comparative Legal Traditions, 67-68.

${ }^{57}$ Mahoney, "The Common Law and Economic Growth," 507.

${ }^{58}$ Youngs, English, French and German Comparative Law, 85.

${ }^{59}$ Andrade, "Comparative Constitutional Law," 979; Cappelletti, "Judicial Review in

Comparative Perspective," 1037-1038.

${ }^{60}$ Andrade, "Comparative Constitutional Law," 980-982; Cappelletti, “Judicial Review in Comparative Perspective," 1040-1041.

${ }^{61}$ Youngs, English, French and German Comparative Law, 47.

${ }^{62}$ Shapiro, "Judicial Independence," 270.

${ }^{63}$ Phillips, "The War on Civil Law?" 916.

${ }^{64}$ Constitution of the Kingdom of Cambodia, 1993, Article 51.

${ }^{65}$ Peng, "The Modern Era of Cambodian Constitutionalism," 39, 52.

${ }^{66}$ Hauerstein, Introduction to Legislative Drafting: References \& Techniques, 14.

${ }^{67}$ Ibid.

${ }^{68}$ Ibid., Article 134.

${ }^{69}$ Human Rights Watch, "Cambodia."

${ }^{70}$ Balasubramaniam, "Judicial Politics in Authoritarian Regimes," 407.

${ }^{71}$ Un, "The Judicial System and Democratization in Post-Conflict Cambodia," 93-94.

${ }^{72}$ Human Rights Watch, "Cambodia."

73 Ibid.

${ }^{74}$ Interview with Cambodian lawyer, Phnom Penh, September 2015.

${ }^{75}$ Interview with international staff member at the ECCC, Phnom Penh, September 2015.

${ }^{76}$ Menzel, "Cambodia," 278-279.

${ }^{77}$ Peou, International Democracy Assistance for Peacebuilding, 98-99.

${ }^{78}$ Interview with Cambodian national working at a local research institute, Phnom Penh, September 2015.

${ }^{79}$ Ibid.

${ }^{80}$ Interview with Cambodian lawyer, Phnom Penh, September 2015.

\section{References}

Andrade, Gustavo Fernandes de. "Comparative Constitutional Law: Judicial Review." Journal of Constitutional Law 3, no. 3 (2001): 977-989. 
Balasubramaniam, Ratna Reuban. "Judicial Politics in Authoritarian Regimes." University of Toronto Law Journal 59, no. 3 (2009): 405-415.

Bedner, Adriaan. "An Elementary Approach to the Rule of Law." Hague Journal on the Rule of Law 2, no. 1 (2010): 48-74.

Bertelman, Hannah. "International Standards and National Ownership? Judicial Independence in Hybrid Courts: The Extraordinary Chambers in the Courts of Cambodia." Nordic Journal of International Law 70 (2010): 341-382.

Bratton, Michael and Nicholas van de Walle. Democratic Experiments in Africa: Regime Transitions in Comparative Perspective. Cambridge: Cambridge University Press, 1997.

Bull, Carolyn. No Entry without Strategy: Building the Rule of Law under UN Transitional Administration. Tokyo: United Nations University Press, 2008.

Burbank, Stephen. "What do we Mean by 'Judicial Independence'?" Ohio State Law Journal 64, no. 1 (2003): 322-339.

Cappelletti, Mauro. "Judicial Review in Comparative Perspective." California Law Review 58, no. 5 (1970): 1017-1053.

Cheesman, Nick. "Thin Rule of Law or Un-Rule of Law in Myanmar." Pacific Affairs 82, no. 4 (2009/2010): 597-613.

Constitution of the Kingdom of Cambodia, 1993.

Dara, Mech and Meta Kong. "PM Intercedes in Kampong Speu Jailings." The Phnom Penh Post, 15 March 2016, http://www.phnompenhpost.com/national/pm-intercedes-kampongspeu-jailings

Dara, Mech and Shaun Turton. "PM Overrules Supreme Court's Decision in Banteay Manchey Land Dispute." The Phnom Penh Post, 24 March 2016, http://www.phnompenhpost.com/national/pm-overrules-supreme-courts-decision-banteaymeanchey-land-dispute

Deinla, Imelda. "Public Support and Judicial Empowerment of the Philippine Supreme Court." Contemporary Southeast Asia 36, no. 1 (2014): 128-158.

Eisenberg, Melvin Aron. The Nature of the Common Law. Cambridge, MA: Harvard University Press, 1998.

Erdmann, Gero and Ulf Engel. "Neopatrimonialism Reconsidered: Critical Review and Elaboration of an Elusive Concept." Commonwealth and Comparative Politics 45, no. 1 (2007): 95-119.

Gainsborough, Martin. "Elites vs. Reform in Laos, Cambodia, and Vietnam." Journal of Democracy 23, no. 2 (2012): 34-46.

Glaesner, Edward and Andrei Shleifer. "Legal Origins." Quarterly Journal of Economics, no. 1, (2004): 1193-1229. 
Glendon, Mary Ann, Michael Wallace and Christopher Osakwe. Comparative Legal Traditions, second edition. St. Paul, MI: West Publishing Co., 1994.

Hauerstein, Kai. Introduction to Legislative Drafting: References \& Techniques. Phnom Penh: Konrad-Adenauer-Stiftung, 2016.

Heder, Stephen. "Cambodia in 2010: Hun Sen's Further Consolidation." Asian Survey 51 no. 1 (2011): 208-214.

Helmke, Gretchen and Frances Rosenbluth. "Regimes and the Rule of Law: Judicial Independence in Comparative Perspective." Annual Review of Political Science 12 (2009): 345-366.

Human Rights Watch. "Cambodia: Withdraw Fundamentally Flawed Judiciary Laws.” 3 May 2014, http://www.hrw.org/news/2014/05/03/cambodia-withdraw-fundamentally-flawedjudiciary-laws

Joireman, Sandra. "Colonization and the Rule of Law: Comparing the Effectiveness of Common Law and Civil Law Countries." Constitutional Political Economy 15, no. 4 (2004): 315-338.

Larkins, Christopher. "Judicial Independence and Democratization: A Theoretical and Conceptual Analysis." The American Journal of Comparative Law 44, no. 4 (1996): 605-626.

Leftwich, Adrian. "Governance, Democracy and Development in the Third World." Third World Quarterly 14, no. 3 (1993): 605-624.

Mahoney, Paul. "The Common Law and Economic Growth: Hayek Might Be Right." The Journal of Legal Studies 30, no. 2 (2001): 503-525.

McCarthy, Stephen and Kheang Un. "The Evolution of Rule of Law in Cambodia." Democratization 24, no. 1 (2017): 100-118.

McCarthy, Stephen and Kheang Un. "The Rule of Law in Illiberal Contexts: Cambodia and Singapore as Exemplars." In Politics and Constitutions in Southeast Asia, edited by Marco Bünte and Björn Dressel, 315-330. London and New York: Routledge, 2017.

Menzel, Jörg. "Cambodia: From Civil War to a Constitution to Constitutionalism?” In Public Law in East Asia, edited by Albert H.Y. Chen and Tom Ginsburg, 259-288. Farnham, UK and Burlington, VT: Ashgate, 2013.

Merryman, John and Rogelio Pérez-Perdomo. The Civil Law Tradition: An Introduction to the Legal Systems of Europe and Latin America. Stanford, CA: Stanford University Press, 2007.

Merryman, John, David S. Clark and John O. Haley. The Civil Law Tradition: Europe, Latin America, and East Asia. Charlottesville, VA: The Michie Company Law Publishers, 1994. 
Merryman, John, David S. Clark and John O. Haley. The Civil Law Tradition: Europe, Latin America, and East Asia, second edition. Charlottesville, VA: The Michie Company Law Publishers, 2000.

Møller, Jørgen and Svend-Erik Skaaning. The Rule of Law: Definitions, Measures, Patterns and Causes. Basingstoke, UK: Palgrave MacMillan, 2014.

Nedzel, Nadia. "The Rule of Law: Its History and Meaning in Common Law, Civil Law, and Latin American Judicial System." Richmond Journal of Global Law and Business 10, no. 1 (2010): 57-109.

Nicholson, Pip and Sally Low. "Local Accounts of Rule of Law Aid: Implications for Donors." Hague Journal on the Rule of Law 5 (2013): 1-43.

Oakeshott, Michael. On Human Conduct. Oxford: Clarendon Press, 1975.

Peerenboom, Randall. Varieties of Rule of Law: An Introduction and Provisional Conclusion. Research Paper no. 03-16, UCLA School of Law, 2004.

Peng, Hor. "The Modern Era of Cambodian Constitutionalism: Constitutional Analysis of Historical and Contemporary Development." In Introduction to Cambodian Law, edited by Hor Peng, Kong Phallack and Jörg Menzel, 23-69. Phnom Penh: Konrad-Adenauer-Stiftung, 2012

Peou, Sorpong. International Democracy Assistance for Peacebuilding: Cambodia and Beyond. Basingstoke and New York: Palgrave MacMillan, 2007.

Peou, Sorpong. "Peace through Retribution or Reconciliation? Some Insights and Evidence from South-East Asia." In The Palgrave Handbook of Disciplinary and Regional Approaches to Peace, edited by Oliver P. Richmond, Sandra Pogodda and Jasmin Ramovic, 336-349. Basingstoke and New York: Palgrave MacMillan, 2016.

Phillips, Emma. "The War on Civil Law? The Common Law as a Proxy for the Global Ambition of Law and Economics.” Wisconsin International Law Journal 24, no. 4 (2007): 915-959.

Piergigli, Valeria. "Transition to Democracy and the Protection of Fundamental Rights: The Problematic Experience of Cambodia." In Asian Constitutionalism in Transition: A Comparative Perspective, edited by Tania Groppi, Valeria Piergigli and Angelo Rinella, 263277. Milan: Giuffrè, 2008.

Raz, Joseph. The Authority of Law: Essays on Law and Morality. Oxford, Clarendon Press, 1979.

Roberts, David. Political Transition in Cambodia 1991-99: Power, Elitism and Democracy. Richmond, Surrey: Curzon, 2001.

Sen, Hun. "The Rule of Law in Cambodia." In Democratic Development: Rule of Law, Occasional Papers, January, 9-12. Phnom Penh: Konrad-Adenauer-Stiftung, 2009. 
Shapiro, Martin. "Judicial Independence: New Challenges in Established Nations." Indiana Journal of Global Legal Studies 20, no. 1 (2013): 253-277.

Sony, Ouch. "PM asked Drunk Driver be Released on Bail." The Cambodia Daily, 7 April 2015, https://www.cambodiadaily.com/archives/pm-asked-drunk-driver-be-released-on-bail$81538 /$

Transparency International. Corruption Perceptions Index 2016.

https://www.transparency.org/news/feature/corruption_perceptions_index_2016\#table

Un, Kheang. "Patronage Politics and Hybrid Democracy: Political Change in Cambodia, 1993-2003." Asian Perspective 29, no. 2 (2005): 203-230.

Un, Kheang. "The Judicial System and Democratization in Post-Conflict Cambodia". In Beyond Democracy in Cambodia: Political Reconstruction in a Post-Conflict Society, edited by Joakim Öjendal and Mona Lilja, 70-100. Copenhagen: Nordic Institute of Asian Studies, 2009.

Un, Kheang. "The Khmer Rouge Tribunal: A Politically Compromised Search for Justice." The Journal of Asian Studies 72, no. 4 (2013): 783-792.

Un, Kheang and Judy Ledgerwood. "Is the Trial of 'Duch' a Catalyst for Change in Cambodia’s Courts?” Asia-Pacific Issues 95 (2010): 1-12.

World Justice Project. WJP Rule of Law Index 2016, https://worldjusticeproject.org/ourwork/wjp-rule-law-index/wjp-rule-law-index-2016

Youngs, Raymond. English, French and German Comparative Law, third edition. Abingdon, UK and New York: Routledge, 2014.

Yu, Seon Bong. "The Role of the Judge in the Common Law and Civil Law Systems: The Cases of the United States and European Countries." International Area Studies Review 2 (1999): 35-36 